\title{
Parallel patterns and trends in functional structures in extinct island mammals
}

\author{
Alexandra A. E. VAN DER GEER \\ Naturalis Netherlands Biodiversity Center, Leiden, Netherlands
}

\begin{abstract}
Endemic mammalian species on islands are generally known to have followed a different evolutionary pathway than their mainland relatives. General patterns, such as body size trends, have been described regularly. However, most island mammal species are unique and each of them is adapted to a specific local niche as part of an equally specific ecological assemblage. Therefore, comparing island species across taxa, islands and time is inherently dangerous without understanding the adaptational value of the studied feature in the compared taxa and without taking the ecological setting of the taxa into account. In this contribution, general and recurring patterns are described per taxon. Some features, like body mass change and sturdy limbs, are relatively general, whereas most features, like bone fusions and change of orbital axis, occur only in a very few taxa. Some features are even contradictory, such as brain size and degree of hypsodonty, with each taxon having its own particular design. In conclusion, general patterns are more often than not just trends and need to be applied with caution.
\end{abstract}

Key words: body proportions, fossil record, island rule, paleo-insular mammals, Pleistocene

\section{INTRODUCTION}

Body size changes, observed in many extant insular mammalian taxa, are certainly the best known adaptations to insular conditions (e.g. van Valen 1973; Heaney 1978; Lomolino 1985, 2005; Lomolino et al. 2012). However, these often spectacular body size changes are not the only modifications of island lineages. Adapta-

Correspondence: Alexandra A. E. van der Geer, Naturalis Netherlands Biodiversity Center, Darwinweg 2, PO Box 9515, 2300 RA Leiden, Netherlands.

Email: alexandra.vandergeer@naturalis.nl tions of island species are also reflected in their craniodental and postcranial anatomy, as first pointed out by Sondaar (1977). Especially in fossil insular mammals, these morphological changes may be so extensive that it is not easy to trace back their direct mainland ancestor. Paleo-insular mammals provide an especially insightful opportunity to assess causality of the variation in morphological structures over much longer time periods. A comprehensive and species-based review of these variations is, however, lacking for the fossil record (general review in van der Geer et al. 2010) and often scattered ad-hoc references to general patterns are given without specific details. This may easily lead to misconceptions in cases where a specific feature of a specific insular taxon is taken for a general pattern exhibited by 
many if not all insular mammalian taxa whereas in reality it is a unique feature of just 1 taxon. To infer a more general pattern from local or superficial similarities is prone to error (Donovan 2013). Such is the case, for example, with some studies on Homo floresiensis Brown et al., 2004 (Brown et al. 2004) where this hominid is put in a broader insular perspective: for example, van Heteren and de Vos (2008), Lyras et al. (2009) and Meijer et al. (2010), who compare the shifts in limb proportions as observed in H. floresiensis with those of a few insular artiodactyls, but not with other insular taxa and without paying much attention to the nature of the individual cases. Although I agree with the hypothesis that $H$. floresiensis represents an insular taxon with specific adaptations, I consider it premature to compare totally unrelated endemic taxa with each other in respect to a feature that appears not to be universal. For example, the short limbs of $H$. floresiensis do not necessarily reflect identical evolutionary adaptations as do those of a dwarf hippo, such as Hippopotamus minor Desmarest, 1822, especially because the structure of the foot of these 2 taxa is totally different: long and plantigrade in the first, and short and unguligrade in the second (also see below).

This review is the first step towards a better understanding of which patterns are shared by which insular mammals and which are not and why this is the case. Until the developmental, functional and adaptational background of these patterns have been reliably explained per taxon, caution should be taken before comparing unrelated taxa.

\section{MATERIALS AND METHODS}

The present study is a review, based on published literature, with the addition of a few personal observations regarding fossil material. Most of the material of the Mediterranean and Indonesian islands cited from the literature was checked by me for control. The cited fossil taxa are given in Table 1, together with their geological age and (paleo-)island.

\section{Observations}

\section{Body size trends}

Body size variation among various lineages of paleoinsular mammals is generally consistent with the graded trend of the island rule (for a comprehensive overview, see Lomolino et al. 2013). Paleo-insular mammals, however, appear to exhibit much more extreme cases of gigantism and dwarfism than living species. Two of the most notorious cases are Palaeoloxodon falconeri Busk, 1867, which decreased to just $2 \%$ of the body mass of its mainland ancestor (Palombo \& Giovinazzo 2005), and Deinogalerix koenigswaldi Freudenthal, 1972, which increased to slightly over 200 times the ancestral body mass (Lomolino et al. 2013).

The most extreme values occur in final species of geologically old endemic lineages. A slight size reduction is more typical for endemic large mammals that are elements of more balanced faunas or that are geologically very young (i.e. during the early stages of isolation) (e.g. Cervus elaphus siciliae Pohlig, 1893, Cervus elaphus Linnaeus, 1758 from Jersey, Bos primigenius siciliae Pohlig, 1911, and Bos primigenius bubaloides Arambourg, 1979) and the earlier species of anagenetic endemic lineages (Myotragus palomboi Bover et al., 2010, Myotragus pepgonellae Moyà-Solà \& PonsMoyà, 1982, Myotragus antiquus Pons-Moyà, 1977, and Praemegaceros sardus van der Made \& Palombo, 2006).

\section{Increased size variation}

Some fossil insular species are characterized by an unusually large variation in body size at any given moment in time. Fossils of smaller and larger specimens are found together in the same layer of the same locality without evidence for clear-cut size groups. This has been observed in Amblyrhiza inundata Cope, 1868 (McFarlane et al. 1998), Hippopotamus creutzburgi Boekschoten \& Sondaar, 1966 (Kuss 1975), Palaeoloxodon creutzburgi (Kuss, 1965) (Kuss 1965), Mammuthus exilis (Stock \& Furlong, 1928) (Roth 1993), Mammuthus protomammonteus (Matsumoto, 1924) (Taruno \& Kawamura 2007) and, perhaps, the Maltese Cervus Linnaeus, 1758 (figured in van der Geer et al. 2010; A. A. E. van der Geer, pers. observ.) (but see remark in Table 1). In these cases, separate species or morphotypes were not recognized.

In a few insular lineages a (much) more pronounced and discontinuous size range is observed and separate species or 'lineages' are recognized. This is the case with the murids of Flores, where the giant Papagomys armandvillei (Jentink, 1892) and Papagomys theodorverhoeveni Musser, 1981 co-occurred with the mediumsized Komodomys rintjanus (Sody, 1941) and Paulamys naso (Musser, 1981) (Meijer et al. 2010; Locatelli 2011), all descendants of Hooijeromys nusatenggara Musser, 1981 (van den Bergh et al. 2008). Another case is provided by the paleo-island Gargano, where the exact biochronological timing of the start of the murid ra- 
Table 1 Fossil insular mammalian taxa discussed in this study. The Maltese deer (Cervus sp.) are unresolved. The larger forms may belong to a younger layer, and the smaller forms, with much size variation, might either represent sister species or chronospecies

\begin{tabular}{|c|c|c|}
\hline Species & Island, geological age & Remarks \\
\hline \multicolumn{3}{|l|}{ Proboscidea } \\
\hline \multicolumn{3}{|l|}{ Elephantidae } \\
\hline Palaeoloxodon falconeri & Sicily, Middle Pleistocene & \\
\hline Palaeoloxodon 'mnaidriensis' & Sicily, Late Pleistocene & \\
\hline Palaeoloxodon creutzburgi & Crete, Late Pleistocene & \\
\hline Palaeoloxodon tiliensis & Tilos, Late Pleistocene & \\
\hline Palaeoloxodon cypriotes & Cyprus, Late Pleistocene & \\
\hline Mammuthus creticus & Crete, Middle Pleistocene & \\
\hline Mammuthus exilis & Santa Rosa, Late Pleistocene & \\
\hline Mammuthus protomammonteus & Japan, Early Pleistocene & \\
\hline Stegoloxodon celebensis & Sulawesi, Middle Pleistocene & \\
\hline \multicolumn{3}{|l|}{ Stegodontidae } \\
\hline Stegodon florensis florensis, S. florensis insularis & Flores, Late Pleistocene & Chrono(sub)species \\
\hline Stegodon sondaari & Flores, Middle Pleistocene & \\
\hline Stegodon aurorae & Japan, Middle Pleistocene & \\
\hline Stegodon sompoensis & Sulawesi, Middle Pleistocene & \\
\hline Stegodon hypsilophus & Java, Middle Pleistocene & \\
\hline Stegodon timorensis & Timor, Pleistocene & \\
\hline Stegodon mindanensis & Mindanao, Philippines, Pleistocene & \\
\hline \multicolumn{3}{|l|}{ Primates } \\
\hline \multicolumn{3}{|l|}{ Hominidae } \\
\hline Oreopithecus bamboli & Tuscany, Late Miocene & \\
\hline Homo floresiensis & Flores, Late Pleistocene & \\
\hline Homo sapiens & $\begin{array}{l}\text { Minatogawa Island, Japan, } \\
\text { Late Pleistocene }\end{array}$ & $\begin{array}{l}\text { Known as Minatogawa } \\
\text { people }\end{array}$ \\
\hline \multicolumn{3}{|l|}{ Lagomorpha } \\
\hline \multicolumn{3}{|l|}{ Leporidae } \\
\hline Nuralagus rex & Menorca, Pliocene & \\
\hline \multicolumn{3}{|l|}{ Ochotonidae } \\
\hline Gymnesicolagus gelaberti & Mallorca, Middle Miocene & $\begin{array}{l}\text { For Menorca: } G \text {. aff. } G \text {. } \\
\text { gelaberti }\end{array}$ \\
\hline Paludotona etruria & Tuscany, Late Miocene & \\
\hline Prolagus figaro, $P$. sardus & Sardinia, Early-Late Pleistocene & Chronospecies \\
\hline Prolagus imperialis & Gargano, Late Miocene & \\
\hline \multicolumn{3}{|l|}{ Rodentia } \\
\hline \multicolumn{3}{|l|}{ Gliridae } \\
\hline Leithia cartei, L. melitensis & Sicily, Middle-Late Pleistocene & Sister species \\
\hline Stertomys laticrestatus & Gargano, Late Miocene & At least seven species \\
\hline $\begin{array}{l}\text { Hypnomys waldreni, H. onicensis, H. morpheus } \\
\text { Cricetidae }\end{array}$ & Majorca, Late Pliocene-Holocene & Chronospecies \\
\hline $\begin{array}{l}\text { Hattomys beetsi, H. nazarii, H. gargantua } \\
\text { Muridae }\end{array}$ & Gargano, Late Miocene & Chronospecies \\
\hline Papagomys armandvillei, $P$. theodorverhoeveni & Flores, Late Pleistocene & Sister species \\
\hline Komodomys rintjanus & Flores, Late Pleistocene & \\
\hline Paulamys naso & Flores, Late Pleistocene & \\
\hline Hooijeromys nusatenggara & Flores, Middle Pleistocene & \\
\hline Kritimys aff. K. kiridus, K. kiridus, $K$. catrei & Crete, Early-Middle Pleistocene & Chronospecies \\
\hline Mus batei, M. minotaurus & Crete, Late Pleistocene & Chronospecies \\
\hline Mikrotia magna, 2 other lineages & Gargano, Late Miocene & Sister lineages \\
\hline
\end{tabular}


A. A. E. van der Geer

Table 1 Continued

\begin{tabular}{|c|c|c|}
\hline Species & Island, geological age & Remarks \\
\hline Huerzelerimys oreopitheci & Tuscany, Late Miocene & \\
\hline Anthracomys majori, A. lorenzi & Tuscany, Late Miocene & \\
\hline \multicolumn{3}{|l|}{ Heptaxodontidae } \\
\hline Amblyrhiza inundata & $\begin{array}{l}\text { Anguilla and Saint Martin, West Indies, } \\
\text { Late Pleistocene }\end{array}$ & $\begin{array}{l}\text { A single island during the Late } \\
\text { Pleistocene (Anguilla Bank) }\end{array}$ \\
\hline \multicolumn{3}{|l|}{ Erinaceamorpha } \\
\hline \multicolumn{3}{|l|}{ Erinaceidae } \\
\hline Deinogalerix koenigswaldi & Gargano, Late Miocene & $\begin{array}{l}\text { Five additional species } \\
\text { within } 2 \text { lineages }\end{array}$ \\
\hline \multicolumn{3}{|l|}{ Soricomorpha } \\
\hline \multicolumn{3}{|l|}{ Soricidae } \\
\hline $\begin{array}{l}\text { Nesiotites rafelinensis, } N \text {. ponsi, } N \text {. aff. N. ponsi, } \\
\text { N. hidalgo }\end{array}$ & Majorca, Early Pliocene-Holocene & Chronospecies \\
\hline \multicolumn{3}{|l|}{ Artiodactyla } \\
\hline \multicolumn{3}{|l|}{ Cervidae } \\
\hline Cervus elaphus siciliae & Sicily, Late Pleistocene & \\
\hline Cervus elaphus & Jersey, Late Pleistocene & \\
\hline Cervus sp. & Malta, Late Pleistocene & Sister or chronospecies \\
\hline Cervus sp. & Masbate, Late Pleistocene & Undescribed species \\
\hline Cervus astylodon & Ryukyu Islands, Late Pleistocene & \\
\hline $\begin{array}{l}\text { Candiacervus ropalophorus, } C \text {. sp. II, C. cretensis, } \\
\text { C. rethymnensis, } C \text {. dorothensis, C. major }\end{array}$ & Crete, Late Pleistocene & Sister species \\
\hline 'Candiacervus' pygadiensis, 'C.' cerigensis & Karpathos, Kassos, Late Pleistocene & Sister species \\
\hline Praemegaceros sardus, $P$. cazioti & Sardinia, Middle-Late Pleistocene & $\begin{array}{l}\text { Chronospecies; earliest form } \\
\text { unnamed: } P . \mathrm{sp} \text {. }\end{array}$ \\
\hline Hoplitomeryx matthei & Gargano, Late Miocene & $\begin{array}{l}\text { Three additional } \\
\text { morphotypes }\end{array}$ \\
\hline \multicolumn{3}{|l|}{ Bovidae } \\
\hline Bos primigenius siciliae & Sicily, Late Pleistocene & \\
\hline Bos primigenius bubaloides & Pianosa, Late Pleistocene & \\
\hline $\begin{array}{l}\text { Myotragus palomboi, M. pepgonellae, M. antiquus, } \\
\text { M. kopperi, M. batei, M. balearicus }\end{array}$ & Majorca, Early Pliocene-Holocene & \\
\hline Bubalus cebuensis & Cebu, Philippines, Late Pleistocene & \\
\hline Dubiosia santeng & Java, Middle Pleistocene & \\
\hline Nesogoral melonii & Sardinia, Early Pleistocene & $\begin{array}{l}\text { Several unnamed sister } \\
\text { species }\end{array}$ \\
\hline Maremmia lorenzi, M. haupti & Tuscany, Late Miocene & Chronospecies \\
\hline Turritragus casteanensis & Tuscany, Late Miocene & \\
\hline Etruria vialli & Tuscany, Late Miocene & \\
\hline Tyrrhenotragus gracillimus & Tuscany, Late Miocene & \\
\hline \multicolumn{3}{|l|}{ Hippopotamidae } \\
\hline Hippopotamus creutzburgi & Crete, Middle Pleistocene & \\
\hline Hippopotamus minor & Cyprus, Late Pleistocene & \\
\hline \multicolumn{3}{|l|}{ Suidae } \\
\hline Sus sondaari & Sardinia, Early Pleistocene & \\
\hline \multicolumn{3}{|l|}{ Carnivora } \\
\hline \multicolumn{3}{|l|}{ Canidae } \\
\hline Cynotherium sardous & Sardinia, Middle-Late Pleistocene & $\begin{array}{l}\text { Earlier chronospecies } \\
\text { unnamed: } C \text {. sp. }\end{array}$ \\
\hline
\end{tabular}


diation has not been recorded. Here, after a steady body size increase, the murids (Mikrotia) display a sudden radiation into 3 lineages contemporaneous with the last occurrence of the hamsters (Hattomys gargantua Freudenthal, 1985). As on Flores, apart from converging on the absent mesoherbivore niche, giant forms exist next to medium and small forms. At the initiation of the murid radiation, the insectivore Deinogalerix is also, for the first time, represented by a full range of body sizes (inferred from Fig. 16 in Butler 1980). Radiation is also seen in Stertomys Daams \& Freudenthal, 1985, with 2 species at any given chronological phase (Rinaldi \& Masini 2009), and Hoplitomeryx (Leinders 1984) (4 morphotypes for Gargano in van der Geer 2005, 2008), but the start of these radiations are not necessarily contemporaneous with the murid radiation.

Such an increased and discontinuous size variation is also observed in other taxa, sometimes in combination with a variation in morphology, independent of size. Examples are Candiacervus (de Vos 1979), Cervus astylodon (Matsumoto, 1926) from Kume (Matsumoto \& Otsuka 2000), Cervus sp. of Masbate (de Vos 2006), subfossil species of lemurs (Mittermeier et al. 2008) and nesomyids (Mein et al. 2010), in addition to the array of still living species of Madagascar, subfossil hystricomorph rodents and soricomorph insecteaters of the West Indies (cladogenesis on Cuba, Puerto Rico and Hispaniola [Woods \& Sergile 2001]), Leithia (Bonfiglio et al. 2002), Malagasy Hippopotamus Linnaeus, 1758 (Weston \& Lister 2009) and Nesogoral (Palombo et al. 2006; Rozzi \& Palombo 2014). The species or morphotypes in these cases are all confined within the boundaries of a single island. The presence of various morphotypes within 1 size class seems restricted to cases of adaptive radiation and has been described only for Nesogoral (Rozzi \& Palombo 2014), Ce. astylodon (de Vos 2006) and Hoplitomeryx (van der Geer 2005; A. A. E. van der Geer, pers. observ.).

In many cases, however, the increased size variation is progressive; in other words, these species form part of a lineage of anagenetic species (chronospecies), with the next species being either smaller or larger than the previous (depending on the direction of body size evolution). Extended chronoseries befitting this type of increased size variation include Praemegaceros of Sardinia (Palombo \& Melis 2005; van der Made \& Palombo 2006), Nesiotites (Rofes et al. 2012; van der Geer et al. 2013), Hypnomys (Bover et al. 2010a), Myotragus (Bover et al. 2010b), Kritimys and Mus of Crete (May- hew 1977), Stegodon florensis Hooijer, 1957 (van den Bergh et al. 2008) and Cynotherium sardous Studiati, 1857 (Lyras et al. 2010): all of them with at least 2 successive chronospecies. The progressive size increase is not always constant, but may show fluctuations in magnitude through time and even reversals (van der Geer $e t$ al. 2013).

\section{Changes in postcranial elements}

Relative shortening of the distal limb bones, with simultaneous overall dwarfing and increased massivity, is observed in several fossil insular artiodactyls, but also in Minatogawa people (Homo sapiens Linnaeus, 1758 [Baba \& Endo 1982]). These artiodactyls are Candiacervus ropalophorus de Vos, 1984, Candiacervus cretensis (Simonelli, 1908) (de Vos 1979), Candiacervus spp. II (van der Geer et al. 2006), 'Candiacervus' pygadiensis (Kuss, 1975), 'Candiacervus' cerigensis (Kuss, 1975), the smallest Hoplitomeryx (van der Geer 2005), Ce. astylodon (de Vos 2006), Bubalus cebuensis Croft et al., 2006 (Croft et al. 2006), all species of Myotragus (Bover 2004; Bover et al. 2010b), H. minor, H. creutzburgi (Spaan et al. 1994), Stegodon aurorae (Matsumoto, 1918) (Konishi 2000) and, perhaps, Maremmia lorenzi Hürzeler \& Engesser, 1976 (Hürzeler 1983) and Etruria vialli Abbazzi et al., 2008, or Turritragus casteanensis Abbazzi et al., 2008, but for these latter 3 taxa the ancestor is unknown. Relatively short legs are also typical for $H$. floresiensis (Brown et al., 2004). The accompanying exceptionally long feet and arms (Brown et al. 2004; Morwood et al. 2005) and primitive wrist (Tocheri et al. 2007; Orr et al. 2013) and foot morphology (Jungers et al. 2009), but are unique and find no parallel with other insular taxa. The feet of $H$. sapiens of Minatogawa are robust but not long (Baba \& Endo 1982). A number of the abovementioned artiodactyls have shortened phalanges in addition to the shorter distal limb bones, so shorter feet (Myotragus, H. minor, $H$. creutzburgi), simultaneously with a change in posture towards a more vertical stance (Sondaar 1977). Distal limb length reduction in lineages which underwent adaptive radiation is restricted to the smallest species or morphotypes. Here, the medium and larger species have slender and proportionally normal or even elongated distal limb bones. This is observed in Candiacervus major (Capasso Barbato \& Petronio 1986) and in the largest Hoplitomeryx (size 4 in van der Geer 2008), but also in Nesogoral (Palombo et al. 2006; Rozzi \& Palombo 2014). 
The relatively shortened distal limb bones is already present at birth and increases further during postnatal ontogeny due to a relatively slower growth speed of the autopodium, at least in C. ropalophorus (van der Geer et al. 2006) and the 2 smallest size classes of Hoplitom$\operatorname{eryx}$ (A. A. E. van der Geer, pers. observ.). The higher massivity of the shortened bones is already observed in neonates of Myotragus balearicus Bate, 1909 (Bover \& Alcover 1999a), C. ropalophorus (van der Geer et al. 2006) and the smallest size classes of Hoplitomeryx (A. A. E. van der Geer, pers. observ.).

Loss of an articulation is sometimes observed in the form of a complete fusion of the navicocuboid with the cannon bone in insular ruminants (Leinders \& Sondaar 1974). This occurs in varying degrees, and is definitely not a universal pattern and not restricted to islands. The percentage of total fusion is $0 \%$ in Praemegaceros cazioti (Depéret, 1897) (Klein Hofmeijer 1997), 0\% in Ce. astylodon (Matsumoto \& Otsuka 2000) (but 45\% according to van der Geer et al. [2010]), 6\% in C. ropalophorus (de Vos 1979), 100\% in Hoplitomeryx (van der Geer 2005) and 21\% in Cervus sp. from Malta (A. A. E. van der Geer, unpub. data). In M. balearicus this percentage differs according to locality and age, and increases from $40 \%$ (Cova de Son Maiol, late Late Pleistocene) to $80 \%$ (Cova de Moleta, Holocene) (Moyá-Solá 1979), strongly indicating the progressive nature of this feature in this species at least. In mainland ruminants, this fusion is rarely observed (e.g. less than $5 \%$ in $E u$ prox/Heteroprox [A. A. E. van der Geer, unpub. data]).

An even more rare fusion is that between the distal parts of the fibula (os malleolare) and tibia, observed only in 1 M. balearicus (Bover et al. 2005) and 1 Hoplitomeryx (van der Geer 2005) out of hundreds of specimens. Synostotic fusions between shafts of individual elements are observed as well, such as the fusion of the lateral metapodals with the cannon bone in Candiacervus sp. II (van der Geer et al. 2006), and more extensive fusion of radius and ulna in Candiacervus sp. II (van der Geer et al. 2006), Hoplitomeryx (A. A. E. van der Geer, unpub. data), P. falconeri, H. minor and Stegodon florensis insularis van den Bergh et al. 2008 (van den Bergh 1999; van den Bergh et al. 2008), and of the tibia-fibula in $P$. falconeri and $H$. minor (van den Bergh 1999). Synostotic fusions have been observed in juvenile S. florensis (van den Bergh 1999) and P. falcone$r i$ (Palombo 2001), indicating that it has nothing to do with aging. Fusion between the metatarsal and the navicocuboid in Hoplitomeryx takes place before the fusion of the distal epiphysis with the shaft (van der Geer
2005) (no information on other ungulates). When the condyles are still separated, the proximal articulation is developed normally, as is the case in mainland deer, e.g. Dama dama (Linnaeus, 1758) (A. A. E. van der Geer, unpub. data).

\section{Changes in dentition}

A higher degree of hypsodonty, or a relative increase in molar crown height, relative to their ancestor is seen in various insular taxa, such as $S$. florensis insularis (van den Bergh et al. 2008), Stegodon sondaari van den Bergh, 1999, Stegodon mindanensis Naumann, 1890, Stegodon hypsilophus Hooijer, 1954, S. aurorae, Stegodon timorensis Sartono, 1969, and Stegodon sompoensis Hooijer, 1964 (e.g. van den Bergh 1999), Mikrotia (Freudenthal 1976), M. balearicus (e.g. Bover 2004), Nesogoral melonii (Dehaut, 1911) (e.g. Palombo et al. 2006), Duboisia santeng (Dubois, 1891) (Rozzi et al. 2013), C. ropalophorus (van der Geer et al. 2006), Sus sondaari van der Made, 1999 (van der Made 1999), Huerzelerimys oreopitheci Engesser, 1989, Anthracomys lorenzi Engesser, 1989, and Anthracomys majori Schaub, 1938 (Casanovas-Vilar et al. 2011), and Kritimys kiridus (Bate, 1942) (Mayhew 1977). Hypsodont teeth are also present in some taxa for which the mainland ancestor is unknown, which leaves it in the middle whether the degree of hypsodonty increased or not. This is valid for Ce. astylodon (Matsumoto 1926), M. lorenzi (Huerzeler 1983) and the other Tusco-Sardinian hypsodont bovids such as Tyrrhenotragus gracillimus (Weithofer, 1888), and T. casteanensis (Abbazzi et al. 2008).

The most extreme form of hypsodonty is exhibited by $M$. balearicus, where the roots of the lower first and second molar even distort normal ossification of the base of the mandibular ramus. This lineage also evolved hypselodontincisors (ever-growing and open-rooted) (Alcover et al. 1981), a character shared with M. lorenzi but because the ancestor of the latter is unknown, it is impossible to determine whether it is an acquired character in Maremmia (Hürzeler \& Engesser 1976) as well. These incisors were earlier regarded as retained primary teeth like in rodents and lagomorphs in which the secondary incisors never erupt (Bover \& Alcover 1999b), but are now considered a modified permanent incisor that erupts at a relatively early ontogenetic stage (Moyà-Solà et al. 2007).

Just larger, but non-hypsodont, teeth are observed in H. floresiensis, relative to H. sapiens and Homo erectus (Dubois, 1894), but not to Homo habilis Leakey et 
al., 1964 (Brown et al. 2004; Brown \& Maeda 2009), whereas smaller teeth seem to characterize Oreopithecus bamboli Gervais, 1872 (Köhler \& Moyà-Solà 1997), pending revision on its ancestry.

Increased masticatory stress is inferred for $H$. sapiens from Minatogawa, based on the extraordinarily strong development of the masticatory muscles, the deep temporal fossae with flared zygomatic arches, the wide and high position of the attachment of the masseter muscles in the zygomata, the thick alveolar bones and a high degree of tooth wear (Baba 2000). In addition, Hypnomys morpheus Bate, 1918 has a more massive mandible relative to that of related Eliomys (Hautier et al. 2009).

Loss of premolars is seen in Hoplitomeryx matthei Leinders, 1984, Myotragus batei Crusafont \& Angel, 1966, M. balearicus (e.g. Alcover et al. 1981), M. lorenzi and $M$. haupti (Hürzeler 1983), T. casteanensis (Abbazzi et al. 2008), C. sardous (Lyras et al. 2006), S. sondaari (van der Made 1999) and H. minor (Boekschoten \& Sondaar 1972). A reduced and perhaps notfunctional p2 is present in N. melonii (Palombo et al. 2006), M. palomboi and Myotragus pepgonellae MoyàSolà \& Pons-Moyà, 1982 (Bover et al. 2010b). Loss of the fourth antemolar is seen in Nesiotites hidalgo Bate, 1944 (Reumer, 1981). Loss of the second and third permanent insicors is seen in Myotragus kopperi Moyà-Solà \& Pons-Moyà 1981 and its younger chronospecies (Moyà-Solà et al. 2007).

More complex enamel patterns are observed in some insular pikas and murids. Mikrotia has an increased number of ridges on the first lower and last upper molar (Freudental 1976), in addition to being hypsodont. All species of Prolagus, in contrast to Paludotona etruria Dawson, 1959, which preserved a plesiomorphic dental morphology, show an increase of enamel complexity of their molars, and an enlargement of the third lower premolars relative to the other lower cheek teeth, without (much) increase in hypsodonty (Angelone 2005). Enamel complexity seems unrelated to hypsodonty: whereas Prolagus imperialis Mazza, 1987 and Prolagus figaro Lopez-Martinez, 1975 combined a very complex pattern with a low hypsodonty index, Prolagus sardus (Wagner, 1832) had a less complex pattern but a higher index.

\section{Cranial and neurological changes}

A lack of strong pneumatization of the skull is seen in the dwarf proboscideans P. falconeri, Mammuthus creticus (Bate, 1907), Mammuthus exilis (Agenbroad et al., 1994) and Stegoloxodon celebensis (Hooijer, 1949). In the most extreme case (P. falconeri), the parietal swellings are entirely lost (Palombo 2001; also see below).

Many insular endemics developed rather short muzzles. In these short-snouted endemics, the maxillary tooth row is more arcuate (A. A. E. van der Geer, pers. observ.) and less complete, as evidenced by the loss or reduction of (pre)molars (H. matthei, M. batei, M. balearicus, M. lorenzi, N. melonii, C. sardous, S. sondaari, H. minor; also see above). A shorter snout in combination with a short diastema is observed (with loss of lower third molar) in Gymnesicolagus gelaberti Mein \& Adrover, 1982 and G. aff. gelaberti, and (without such loss) in and Nuralagus rex Quintana et al., 2011 (Quintana et al. 2011), but not in P. sardus (Quintana \& Agustí 2007) and Deinogalerix koenigswaldi Freudenthal, 1972 (Butler 1980), which have an increased diastema length. A marked facial reduction or reduced prognathism (the homonin equivalent of a shorter muzzle) is also seen in H. floresiensis (Kaifu et al. 2011). In this aspect, H. floresiensis is most similar to H. sapiens, but in all other characters combined it resembles $H$. erectus most (Baab \& McNulty 2009; Lyras et al. 2009; Kaifu et al. 2011; Orr et al. 2013). One of its unique features is the posteriorly positioned caudal border of the palatine (Kaifu et al. 2011).

A brain of the same relative size as in their mainland relatives has been documented for Candiacervus spp. II, C. sardous and H. minor (Lyras et al. 2009), whereas that of $P$. falconeri is proportionally equally large or perhaps even larger (Palombo 2001). Brain size reduction, in contrast, has been described for M. balearicus (Köhler \& Moyà-Solà 2004), Hippopotamus lemerlei Milne-Edwards, 1868 and Hippopotamus madagascariensis Guldberg, 1883 (Weston \& Lister 2009). The brain of $M$. balearicus is further characterized by a reduced visual cortex (Köhler \& Moyà-Solà 2004), matching the smaller orbits (see below), and unusually small olfactory bulbs (Desachaux 1961), which agrees with the reduced olfactory ability as inferred from the less perforated criba nasalis (Bover \& Tolosa 2005). Simultaneously, however, the Myotragus brain is remarkably convoluted for its size (Dechaseaux 1961), resulting in a significant increase in cortical surface. H. floresiensis has a relative brain size comparable to that of an australopithecine (Brown et al. 2004; Falk et al. 2005), but anatomical features of the brain resemble those of $H$. erectus most, although with a more pronounced convolution (Falk et al. 2005), similar to M. balearicus. 


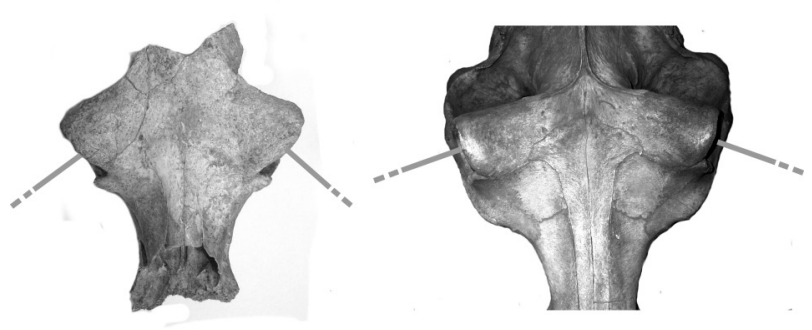

Figure 1 Skulls of Hippopotamus minor (right) and H. amphibius (left) show a more frontal view of the insular dwarf as compared to that of a mainland hippo. Note that the skulls are not depicted with the same scale. Maximal biorbital breadth is $13.5 \mathrm{~cm}$ for $H$. minor and $32 \mathrm{~cm}$ for $H$. amphibius.

In M. balearicus and less so in C. ropalophorus, the orbits are reduced in size relative to body size (Palombo et al. 2008). At the same time, the orbits are more frontally orientated in M. balearicus (Alcover et al. 1981). This is also observed in H. minor (Fig. 1).

\section{DISCUSSION}

\section{Body size trends}

In a comprehensive investigation of causality of the island rule in extant mammals, Lomolino et al. (2012) found that body size evolution is influenced by selective forces whose importance and nature of influence (promoting gigantism or dwarfism) varied in a predictable manner with characteristics of the species (in particular, their ancestral body size and diet) and the islands (island size, isolation and climate), and with ecological interactions among mammals.

The existence of a clade-dependent pattern cannot be confirmed for the fossil record, in contradiction to the conclusion of Meiri et al. (2008) that heteromyid rodents, carnivores and artiodactyls typically evolve smaller size on islands whereas murid rodents usually grow larger. Lomolino et al. (2013) found that proboscideans also grow smaller, and that shrews, gymnures, lagomorphs, glirids and carnivores with aquatic prey grow larger. This contradiction might, in part, stem from a time bias, because most island taxa included in Meiri et al. (2008) originate from continental islands that had been connected to the mainland during the last glacial maximum, and, thus, had been isolated for, at most, 10000 years (Locatelli et al. 2012), whereas most taxa included in Lomolino (2013) had been isolated since the onset of the Late Pleistocene. In addition, and this is perhaps the main issue, truly giant and dwarf forms like Leithia, Papagomys Sody 1941, Deinogalerix, P. falconeri and $H$. minor were not included in the Meiri et al. (2008) analyses because no living mainland conspecific exists (Locatelli et al. 2012). Dwarfism is sometimes described as pedomorphism, e.g. Roth (1992), Lister (1996) and Palombo (2001) for dwarf elephants and van Heteren \& de Vos (2008) for H. floresiensis. I disagree with this hypothesis, because adult insular endemics do not resemble the juveniles of the ancestral species. Especially juvenile artiodactyls, and elephants to a lesser degree, have typically long and slender limbs (not short as van Heteren \& de Vos [2008] assume), whereas insular dwarf artiodactyls and proboscideans have short and massive limbs. Dwarfism likely is established by a reduction of growth speed and not by a truncation of growth length as there is no evidence that life history traits would scale allometrically (Clauss et al. 2014). Maximum lifespan and gestation period in island dwarfs tend to reflect those of their larger relatives (Clauss et al. 2014; see further below). A slower growth speed is also attested for molar formation in a dwarf elephant species (Dirks et al. 2012), whereas Bromage et al. (2002) calculated a similar growth speed between Palaeoloxodon cypriotes (Bate, 1903) and the mainland Palaeoloxodon recki (Dietrich, 1915), based on the number of cross-striations and striae of Retzius in molars (see further below under Dentition). However, P. recki is phylogenetically distinct from Palaeoloxodon antiquus (Falconer \& Cautley, 1847) (the ancestor of P. cypriotes), whose growth speed is unknown. Studies of extant insular taxa also indicate a slower, not a faster, life. Lower basal metabolic rates have been found in fruit pigeons on small islands in the South Pacific and for Capromys pilorides (Say, 1822), Geocapromys browni Fischer, 1830 and Geocapromys ingrahami (Allen, 1891) of the West Indies (McNab 2000), and small nectar-eating flying foxes (Macroglossus, Syconycteris) of Australia and New Guinea and on large and small islands from the Moluccas to the Solomons readily enter torpor (Bonacorso \& McNab 1997).

\section{Increased size variation}

A very interesting effect of release from competition on body size evolution is the increased size and morphological variation. The most typical cases are referred to as adaptive radiation or multispecies assemblages. Body size evolution in these cases is likely directed to- 
wards niche partitioning, resulting in the filling of all usual (mainland) roles, with much morphological convergence. Living examples are the tenrecs of Madagascar (Tenrecidae). The Tenrecidae are a widely diverse family with species ranging from approximately $5 \mathrm{~g}$ to just over $1 \mathrm{~kg}$ and occupying niches convergent to those of shrews, desmans, hedgehogs and opossums in diverse environments (aquatic, terrestrial, arboreal and fossorial). The insular fossil record contains quite a number of sympatric multispecies assemblages, including herbivores, rodents and insect eaters. Even very large herbivores might be able to diverge morphologically and evolve into 2 different species when the area is large enough, as is the case with $H$. madagascariensis and H. lemerlei on Madagascar. Radiations sometimes were more extensive in the past than today: for example, the Malagasy lemurs were further represented by 15 now extinct species before the Holocene, including the gorilla-sized giant Megaladapis Forsyth Major, 1894 (Mittermeier et al. 2008), and the diversity of most lineages of the West Indies was larger during the Pleistocene than it is today (Woods \& Sergile 2001).

\section{Changes in postcranial elements}

Change in body proportions is perhaps best explained in terms of niche expansion. Large herbivores might need to enhance their climbing abilities and improve stability to be able to expand their niche to otherwise inaccessible mountainous areas (Sondaar 1977). This is the most common explanation behind the observed shortening and thickening of the long bones, most markedly the metapodials in ungulates and the femur and humerus in proboscideans and hippos. Increased stability is, in a few cases, further achieved by a restriction of directions of movements and the degree thereof through bone fusions. The inherent loss of speed and manoeuvrability ('low-gear system' in Sondaar [1977]) pose no problem when terrestrial mammalian predators are lacking. Short, robust limbs in H. floresiensis, in contrast, need not necessarily have the same adaptational background. Long limbs in humans did not evolve to outrun predators as is the case in ungulates but are in all likelihood better explained in terms of locomotor efficiency and endurance (Polk 2004). On Flores, the loss of migratorial habits may have driven the reversion of morphology instead. Another scenario could be that $H$. floresiensis simply returned to the (rain) forest and was no longer adapted to open environments. The proportionally long arms and feet of $H$. floresiensis fit an arboreal adaptation very well.
In a few cases, the short, robust limbs form a plesiomorph feature. Niche expansion is not the case here but was earlier a conservative trait that managed to survive under reduced ecological pressure. This might be partly the case for Myotragus, as it has been suggested that its ancestor already had short, robust metapodials (i.e. Palombo et al. [2013] suggest Norbertia or Aragoral as potential candidates). In the case of $H$. floresiensis, this might indicate a pre-erectus ancestry, as is currently the consensus opinion of the discovery team (see Morwood \& Jungers 2009). However, Neanderthals also have proportionally shorter limbs (Polk 2004).

The changes in body proportions relative to the ancestor are likely the result of changes in relative growth speed of the various body parts (heterochrony) during ontogeny (van Heteren \& de Vos 2008). This, however, does not explain the fusion of the cannon bone with the navicocuboid. Because this fusion takes place in an early developmental stage, and not in adulthood, it might be related to a local inhibition of the expression of articular surfaces to enable fusion. Bone fusions are difficult to explain in terms such as heterochrony and are certainly not to be considered pedomorphism. Information on synostotic fusions and how and at what age they occur is even scantier, but there is an indication that this starts at a young age (see above for $S$. florensis insularis) In any case, fusions are extremely rare, also in insular taxa, with as the only exception that of the metatarsal with the tarsal bone in Myotragus and Hoplitomeryx.

\section{Dentition, diet and longevity}

A higher degree of hypsodonty in insular mammals is often explained as an adaptation towards more abrasive food (Schüle 1993). This is evidenced by M. balearicus, which fed on less nutritive or even toxic plants like Buxus balearica Lamarck, 1785 (Alcover et al. 1999; Winkler 2010), implying an increased digestive effort, perhaps combined with a longer intestinal tract, resulting in a relatively large belly or a change in intestinal bacterial fauna (Bover 2004).

Another hypothesis is a response to increased food intake, in line with an increased metabolic rate in dwarf forms due to a shift in volume-surface ratio, and, correspondingly, a 'fast' life (Raia et al. 2003). This increase would result in more rapid tooth wear, which is compensated for by an increase in hypsodonty. The 'fast' life was originally forwarded for P. falconeri, based upon the lack of tusks in the females and a high percentage of juveniles (Raia et al. 2003), but has also been sug- 
gested for other insular proboscideans (Palombo 2007), M. balearicus (Meiri \& Raia [2010] contra Köhler \& Moyà-Solà [2010]; also see below) and $H$. floresiensis (van Heteren \& de Vos 2008). However, this hypothesis fails to explain similar strategies to reduce tooth wear in insular giant taxa, where metabolic rate, if changed, would be lower compared to their normal-sized ancestors, due to the same volume-surface ratio shift, resulting in a 'slower' life. The anoa [Bubalus depressicornis (Hamilton-Smith, 1827)], an extant island dwarf buffalo, has a surprisingly high longevity and an extremely long gestation time for its body size, which stands in sharp contrast to a 'faster' life. Likely, its maximum lifespan and gestation period reflect those of its larger relatives (Clauss et al. 2014), as is also the case for domestic breeds: dwarf breeds of horses, dogs, rabbits, goats and cattle have the same values as large-sized and normal-sized breeds (overview in Clauss et al. 2014). There is no evidence that life history traits would scale allometrically (Clauss et al. 2014).

A 'slower' life, in contrast, has been suggested for $M$. balearicus based on lines of arrested growth in bones (Köhler \& Moyà-Solà 2010) and the number of cementum layers of its teeth (Jordana et al. 2012), which imply a higher maximum lifespan for Myotragus than for similar-sized extant bovids. Without predators around, investment in K-strategy pays off and longevity is a means to achieve this. In line with this is the observation that tooth growth appears to be slow in a small fossil insular elephant species (P. cypriotes) but fast in a large fossil mainland species (Mammuthus columbi Falconer, 1857) (Dirks et al. 2012). Jordana et al. (2012) go a step further and maintain that the coexistence of hypsodonty and longevity in $M$. balearicus is entirely interlinked and of a causal nature, with diet playing no role at all. However, the incisors of Myotragus are ever-growing while the molars are just (extremely) hypsodont, implying that the prolonged tooth wear did not affect all positions equally and that the attrition-abrasion gradient varied along the tooth row. The ever-growing incisors show that incisal preparation was significantly more demanding, which is unexpected for a browser. It is more likely that the incisors evolved their ever-growing capability in response to something other than just longevity. As far as the molar crowns are considered, their hypsodonty may, indeed, have evolved partly in response to the demands of an extended lifespan.

The response to diet-induced abrasion, resulting in hypsodonty and complex enamel patterns, could also be a reaction to a change in eating methods, including rooting, overgrazing and near-surface browsing, result- ing in a significant soil particle intake (Damuth \& Janis 2011). This latter factor should not be underestimated. There is evidence of high tooth wear in sheep that graze among the highly mobile and windswept sandy beaches and dunes on the west side of New Zealand's North Island (Healy \& Ludwig 1965). Soil mineral particles are very mobile in beach environments, and onshore or littoral winds are always strongest right at the beach. Islands are, in general, more windy than mainlands of the same latitude. A higher intake of mineral particles could, therefore, form an important factor to explain hypsodonty in insular taxa.

An alternative strategy to cope with a higher degree of abrasion seems to have been implemented by $\mathrm{H}$. $\mathrm{sa}$ piens of Minatogawa, where the skull architecture indicates heavy action of the masticatory muscles, but where the teeth had not responded adequately, as shown by a high degree of wear (Baba 2000). In this case, it is unlikely to assume either a fast life or increased longevity. The same seems to apply to H. morpheus with its more massive mandible relative to that of related Eliomys but without having evolved particular hypsodont or complex dentition (Hautier et al. 2009). This, in combination with microwear patterns, is explained as an adaptation towards a more abrasive and generalized diet, and not as a longevity strategy. This seems contrary to the case of other insular murids; namely, Huerzelerimys and Anthracomys. The increased wear-resistancy observed here as well as in the contemporaneous bovids of the same insular bioprovince is in conflict with paleobotanical evidence that shows that grasses formed only a minor component of the vegetation (Casanovas-Vilar et al. 2011). Increased particle intake is, however, not considered here, whereas it could be a logic explanation for the high degree of hypsodonty seen in most members of this fauna.

\section{Cranial changes}

Usually, the lack of strong pneumatization of the skull in insular dwarf proboscideans is explained as a response to size reduction because a smaller and, thus, lighter skull relaxes the need for strong neck musculature (Accordi \& Palombo 1971; Sondaar 1977).

The relatively short muzzles may be an adaptation to a higher degree of tooth wear (in herbivores) or towards a higher degree of hypercarnivory (in carnivores). However, not all cases of relatively short snouts are an insular adaptation. For example, the short diastema in insular lagomorphs represents a retained plesiomorphic character (Quintana \& Agusti 2007). 
Relative shortening of the muzzle might result in a relative increase in power exerted at the molariforms (Reilly et al. 2001). In hypercarnivorous carnivores (e.g. Lycaon pictus (Temminck, 1820), felids), snout length and number of molariforms are reduced. This model fits C. sardous best (Lyras et al. 2006). In contrast, the facial reduction observed in $H$. floresiensis is attributed to reduced masticatory stresses (Kaifu et al. 2011) instead. This would oppose $H$. floresiensis to carnivores, although there is evidence that the teeth of $H$. floresiensis are large relatively to $H$. sapiens and $H$. erectus (Brown et al. 2004), perhaps implying an increased masticatory stress. At the same time, the more caudally positioned caudal palatine border of $H$. floresiensis is found without exception in short-faced wild and fossil canids relative to their long-faced relatives (Lyras 2009). Morphogenetic factors that affect the shortening of the facial region seem also to affect the position of the posterior palatine border, independent of changes in masticatory function.

\section{Neurological changes}

Brain size is sometimes reduced with a simultaneous increase in complexity (convolution), retaining in this way a larger surface area. This is the case in M. balearicus and perhaps in H. floresiensis as well. Future studies on the brain of insular taxa should not take only brain mass into account but measure surface area as well. In that respect, effective brain size may appear to be similar to that of the ancestor.

Decrease in olfactory and/or visual functions may be promoted by a shift in predator pressure.

\section{CONCLUSION}

Putting all observations together, it appears that some parallel phenomena exist among insular taxa, but none of them is shown by all and most of them are shown by just a few or even only 2 . The most widespread phenomena are those concerning body size and body proportions, the rarest bone fusions. Some phenomena are even contradictory, such as limb length and brain size, which can be either reduced or enlarged.

The parallel patterns and trends that are present are functionally best explained by shared adaptational needs (adaptations to ecologically similar environments and assemblages) in response to a deviation from the ancestral (mainland) situation, such as more rugose terrain, higher abrasiveness of the food items, increased intraspecific competition and change in predator spectrum.
Caution should be taken when comparing parallel adaptations in unrelated taxa: short limbs in an ungulate may indicate rugose terrain but in a hominid perhaps an arboreal habitat. Such comparisons can even be inopportune between related taxa. See, for example, Rozzi \& Palombo (2014), who found that different habitats triggered similar adaptations within a genus of insular bovids (Nesogoral).

As a result of restructuring of anatomical units, some characters may depart from their apomorphic condition, and may even secondarily return to a condition shared with geologically earlier members of the taxon. This is sometimes referred to as a return to a primitive condition (e.g. van der Geer 2005) but that phrase is misleading as it gives the impression that the entire anatomical structure lost its apomorphic morphology and, as a whole, returns to a plesiomorphic stage. This is, however, explicitly not the case. The brain may be smaller in size in insular endemics ('pseudo-primitive'), but, at the same time, its fissuration can be significantly stronger (apomorphic). To complicate the matter even more, a seemingly apomorphic feature, increased longevity (and gestation period) in insular large mammals relative to similar-sized mammals, is probably unrelated to body mass but likely merely reflects the values of the ancestor and is, thus, rather, a plesiomorphic feature. Developmental speed is then necessarily slower in secondary dwarfs (because gestation length is fixed) and this may be indirectly advantageous in an environment with more pronounced fluctuations in resource availability, resulting in decreased size.

This confusion between apomorphic and plesiomorphic conditions may drastically complicate phylogenetic and taxonomical analyses. The immediate danger of this is that arrival time may be calculated far too much in the past and time in isolation may be hugely overestimated.

\section{ACKNOWLEDGMENTS}

This paper was greatly improved thanks to discussions I had with John de Vos, George Lyras, Lars van den Hoek Ostende, Richard Madden, Marcus Clauss, Hanneke Meijer, Roberto Rozzi, Victoria Herridge and Christine Hertler. I am indebted to the following people at museums and institutions for granting access to the material in their care and for their kind help: Reinier van Zelst (Leiden), Elisabetta Cioppi (Florence), Loic Costeur (Basel), George Theodorou (Athens and Rethymnon), John Borg (Malta), Maria Rita Palombo (Rome), Reinhard Ziegler (Stuttgart), Christine Argot and Stéph- 
anie Renault (Paris), Marisa Arca and Caterinella Tuvieri (Nuoro), and Gian Luigi Pillola (Cagliari). I further wish to thank the guest editor Maria Rita Palombo for inviting me to submit a manuscript. This research has been co-financed by the European Union (European Social Fund) and Greek national funds through the operational program 'Education and Lifelong Learning' of the National Strategic Reference Framework (NSRF)-Research Funding Program: Thalis-UOA Island biodiversity and cultural evolution: examples from the Eastern Mediterranean, Madagascar, Mauritius and Philippines during the past 800000 years (70/3/11669, MIS: 375910).

\section{REFERENCES}

Abbazzi L, Delfino M, Gallai G, Trebini L, Rook L (2008). New data on the vertebrate assemblage of Fiume Santo (northwest Sardinia, Italy), and overview on the Late Miocene Tusco-Sardinian palaeobioprovince. Palaeontology 51, 425-51.

Accordi FS, Palombo MR (1971). Morfologia endocranica degli elefanti nani pleistocenici di Spinagallo (Siracusa) e comparazione con l'endocranio di Elephas antiquus. Rendiconti dell' Accademia Nazionale del Lincei (Series 8) 51, 111-24.

Alcover JA, Moyà-Solà S, Pons-Moyà J (1981). Les Quimeres dels Passat. Els Vertebrats fòssils del PlioQuaternari de les Balears i Pitiüses. Monografies Cientifiques 1, 1-260.

Alcover JA, Perez-Obiol R, Errikarta-Imanol Y, Bover P (1999). The diet of Myotragus balearicus Bate 1909 (Artiodactyla: Caprinae), an extinct bovid from the Balearic Islands: evidence from coprolites. Biological Journal of the Linnean Society 66, 57-74.

Angelone C (2005). Evolutionary trends in dental morphology of the genus Prolagus (Ochotonidae Lagomorpha) in the Mediterranean islands. Monografies de la Societat d'Història Natural deles Balears $\mathbf{1 2}$, 17-26.

Baab KL, McNulty KP (2009). Size, shape and asymmetry in fossil hominins: the status of the LB1 cranium based on 3D morphometric analyses. Journal of Human Evolution 57, 608-22.

Baba H (2000). Physical adaptations of the Minatogawa people to island environments. Tropics 10, 231-41.

Baba H, Endo B (1982). Postcranial skeleton of the Minatogawa Man. University Museum Bulletin 19, 61159.
Boekschoten GJ, Sondaar PY (1972). On the fossil mamalia of Cyprus. Proceedings of the Koninklijke Nederlandse Akademie van Wetenschappen (Series B) 75, 306-38.

Bonaccorso F, McNab B (1997). Plasticity of energetics in blossom bats (Pteropodidae): impact on distribution. Journal of Mammalogy 78, 1073-88.

Bonfiglio L, Mangano G, Cinzia A et al. (2002). Pleistocene Calabrian and Sicilian bioprovinces. Geobios $\mathbf{5}$, 29-39.

Bover P (2004). Noves aportacions al coneixement del gènere Myotragus Bate, 1909 (Artiodactyla, Caprinae) de les illes Balears (PhD dissertation). Universitat de les Illes Balears, Palma de Mallorca.

Bover P, Alcover JA (1999a). Estimating physical characteristics of neonate Myotragus balearicus (Artiodactyla, Caprinae). Deinsea 7, 33-54.

Bover P, Alcover JA (1999b). The evolution and ontogeny of the dentition of Myotragus balearicus Bate, 1909 (Artiodactyla, Caprinae): evidence from new fossil data. Biological Journal of the Linnean Society 68, 401-28.

Bover P, Tolosa F (2005). The olfactory ability of Myotragus balearicus: preliminary notes. Monografies de la Societat d'Història Natural de les Balears 12, 8594.

Bover P, Fornós JJ, Alcover JA (2005). Carpal bones, carpal fusions and footprints of Myotragus: clues for locomotion and behavior. Monografies de la Societat d'Història Natural de les Balears 12, 59-72.

Bover P, Alcover JA, Michaux JJ, Hautier L, Hutterer R (2010a). Body shape and life style of the extinct Balearic dormouse Hypnomys (Rodentia, Gliridae): new evidence from the study of associated skeletons. PLOS ONE 5, e15817.

Bover P, Quintana J, Alcover JA (2010b). A new species of Myotragus Bate, 1909 (Artiodactyla, Caprinae) from the Early Pliocene of Mallorca (Balearic Islands, western Mediterranean). Geological Magazine 147, 871-85.

Bromage TH, Dirks W, Erdjument-Bromage $\mathrm{H}$ et al. (2002). A life history and climate change solution to the evolution and extinction of insular dwarfs: a Cypriot experience. In: Waldren WH, Ensenyat JA, eds. World Islands in Prehistory: International Insular Investigations. Palma de Mallorca, pp. 420-7.

Brown P, Maeda T (2009). Liang Bua Homo floresiensis mandibles and mandibular teeth: a contribution to the 
comparative morphology of a new hominin species. Journal of Human Evolution 57, 571-96.

Brown P, Sutikna T, Morwood MJ et al. (2004). A new small-bodied hominin from the Late Pleistocene of Flores, Indonesia. Nature 403, 1055-61.

Butler PM (1980). The giant erinaceid insectivore Deinogalerix Freudenthal from the Upper Miocene of the Gargano, Italy. Scripta Geologica 57, 1-72.

Capasso Barbato L, Petronio C (1986). Cervus major $\mathrm{n}$. sp. of Bate Cave (Rethymnon, Crete). Atti della Accademia Nazionale dei Lincei, Memorie, classe di Scienze fisischi, matematische e naturali (Serie 8, 2a) 18, 59-100.

Casanovas-Vilar I, van Dam JA, Moyà-Solà S, Rook L (2011). Late Miocene insular mice from the TuscoSardinian palaeobioprovince provide new insights on the palaeoecology of the Oreopithecus faunas. Journal of Human Evolution 61, 42-9.

Clauss M, Dittmann MT, Dennis WH, Zerbe P, Codron D (2014). Low scaling of a life history variable: analysing eutherian gestation periods with and without phylogeny-informed statistics. Mammalian Biology 79, 9-16.

Croft DA, Heaney LR, Flynn JJ, Bautista A (2006). Fossil remains of a new, diminutive Bubalus (Artiodactyla: Bovidae: Bovini) from Cebu Island, Philippines. Journal of Mammology 87, 1037-51.

Damuth J, Janis CM (2011). On the relationship between hypsodonty and feeding ecology in ungulate mammals, and its utility in palaeoecology. Biological Reviews 86, 733-58.

de Vos J (1979). The endemic Pleistocene deer of Crete. Proceedings of the Koninklijke Akademie van Wetenschappen (Series B) 82, 59-90.

de Vos J (2006). Notes about parallels in the evolution of the Pleistocene cervids from Greece (Crete, Kassos and Karpathos), Japan (the Ryukyu-islands) and Philippines (Masbate). Hellenic Journal of Geosciences 41, 127-40.

Dechaseaux C (1961). Moulages endocraniennes de bovidés fossiles. Annales de Paléontologie 47, 51-73.

Dirks W, Bromage TG, Agenbroad LD (2012). The duration and rate of molar plate formation in Palaeoloxodon cypriotes and Mammuthus columbi from dental histology. Quaternary International 255, 79-85.

Donovan SK (2013). Misinterpreting by localism: transposing European geology and tectonics onto Jamaica and the Antilles. Proceedings of the Geologists' Association 124, 530-5.
Falk D, Hildebolt C, Smith K et al. (2005). The brain of LB1, Homo floresiensis. Science 308, 242-5.

Freudenthal M (1976). Rodent stratigraphy of some Miocene fissure fillings in Gargano (prov. Foggia, Italy). Scripta Geologica 37, 1-23.

Freudenthal M (1985). Cricetidae (Rodentia) from the Neogene of Gargano (Prov. of Foggia, Italy). Scripta Geologica 77, 29-74.

Hautier L, Bover P, Alcover JA, Michaux J (2009). Mandible morphometrics, dental microwear pattern and palaeobiology of the extinct Balearic Dormouse Hypnomys morpheus. Acta Palaeontologica Polonica 54, 181-94.

Healy WB, Ludwig TG (1965). Ingestion of soil by sheep in New Zealand in relation to wear of teeth. Nature 208, 806-7.

Heaney LR (1978). Island area and body size of insular mammals: evidence from the tri-colored squirrel (Callosciurus prevosti) of Southeast Asia. Evolution 32, 29-44.

Hürzeler J (1983). Un alcéphaliné aberrant (Bovidae: Mammalia) des Lignites de Grosseto en Toscane. Comptes Rendus de Academie des Sciences de Paris 295, 697-701.

Jordana X, Marín-Moratalla N, DeMiguel D, Kaiser TM, Köhler M (2012). Evidence of correlated evolution of hypsodonty and exceptional longevity in endemic insular mammals. Proceedings of the Royal Society B 279 (1741), 3339-46.

Jungers WL, Harcourt-Smith WEH, Tocheri MW et al. (2009). The foot of Homo floresiensis. Nature 459, 81-4.

Kaifu Y, Baba H, Sutikna T et al. (2011). Craniofacial morphology of Homo floresiensis: description, taxonomic affinities, and evolutionary implication. Journal of Human Evolution 61, 644-82.

Klein Hofmeijer G (1997). Late Pleistocene deer fossils from Corbeddu Cave. British Archaeological Reports International Series 663, 432-663.

Köhler M, Moyà-Solà S (1997). Ape-like or hominidlike? The positional behavior of Oreopithecus bambolii reconsidered. PNAS 94, 11747-50.

Köhler M, Moyà-Solà S (2004). Reduction of brain size reduction and sense organs in the fossil insular bovid Myotragus. Brain, Behavior and Evolution 63, 12540.

Köhler M, Moyà-Solà S (2010). Physiological and life history strategies of a fossil large mammal in a resource-limited environment. PNAS 106, 20354-8. 
Konishi S (2000). Skeletal restration of Stegodon aurorae (Proboscidea, Mammalia) and its feature: case study in the Taga specimen. Earth Science 54, 26878.

Kuss SE (1965). Eine pleistozäne Säugetierfauna der Insel Kreta. Berichte der Naturforschenden Gesellschaft zu Freiburg im Breisgau 55, 271-348.

Kuss SE (1975). Hippopotamus creutzburgi parvus n. spp., ein pleistozänes Zwergflusspferd von der Insel Kreta. Berichte der Naturforschenden Gesellschaft zu Freiburg im Breisgau 65, 5-23.

Leinders JJM (1984). Hoplitomerycidae fam. nov. (Ruminantia, Mammalia) from Neogene fissure fillings in Gargano (Italy). Scripta Geologica 70, 1-51.

Leinders JJM, Sondaar PY (1974). On functional fusions in footbones of ungulates. Zeitschrift für Säugetierkunde 39, 109-15.

Locatelli E (2011). Insular Small Mammals from Quaternary Deposits of Sicily and Flores $(\mathrm{PhD}$ dissertation). Università degli Studi di Ferara, Ferara.

Locatelli E, Rokus Awe Due, van den Bergh GD, van den Hoek Ostende LW (2012). Pleistocene survivors and Holocene extinctions: the giant rats from Liang Bua (Flores, Indonesia). Quaternary International 281, 47-57.

Lomolino MV (1985). Body size of mammals on islands: the island rule reexamined. The American Naturalist 125, 310-6.

Lomolino MV (2005). Body size evolution in insular vertebrates: generality of the island rule. Journal of Biogeography 32, 1683-99.

Lomolino MV, Sax DF, Palombo MR, van der Geer AAE (2012). Of mice and mammoths: evaluations of causal explanations for body size evolution in insular mammals. Journal of Biogeography 39, 842-54.

Lomolino MV, van der Geer AA, Lyras GA, Palombo MR, Sax DF, Rozzi R (2013). Of mice and mammoths: generality and antiquity of the island rule. Journal of Biogeography 40, 1427-39.

Lyras GA (2009). The evolution of the brain in Canidae (Mammalia: Carnivora). Scripta Geologica 139, $1-93$.

Lyras GA, van der Geer AAE, Dermitzakis MD, de Vos J (2006). Cynotherium sardous, an insular canid (Mammalia: Carnivora) from the Pleistocene of Sardinia (Italy), and its origin. Journal of Vertebrate Paleontology 26, 735-45.
Lyras GA, Dermitzakis MD, van der Geer AAE, van der Geer SB, de Vos J (2009). The origin of Homo floresiensis and its relation to evolutionary processes under isolation. Anthropological Science 117, 33-43.

Lyras GA, van der Geer A, Rook L (2010). Body size of insular carnivores: evidence from the fossil record. Journal of Biogeography 37, 1007-21.

Matsumoto H (1926). On some new fossil cervicorns from Kazusa and Liukiu. Scientific Report of Tohoku Imperial University Series 2 (Geology) 10, 17-25.

Matsumoto Y, Otsuka H (2000). Morphotypes of fossil deer (Cervus astylodon) and its miniaturization process. Tropics 10, 145-54.

Mayhew DF (1977). The endemic Pleistocene murids of Crete I-II. Proceedings of the Koninklijke Akademie van Wetenschappen (Series B) 80, 182-214.

McFarlane DA, MacPhee RDE, Ford DC (1998). Body size variability and a Sangamonian extinction model for Amblyrhiza, a West Indian megafaunal rodent. Quaternary Research 50, 80-9.

McNab BK (2000). The influence of body mass, climate and distribution on the energetics of South Pacific pigeons. Comparative Biochemistry and Physiology (Part A: Molecular \& Integrative Physiology) 127, 309-29.

Meijer HJM, van den Hoek Ostende LW, van den Bergh GD, de Vos J (2010). The fellowship of the hobbit: the fauna surrounding Homo floresiensis. Journal of Biogeography 37, 995-1006.

Mein P, Sénégas F, Gommery D, Ramanivoso B, Randrianantenaina H, Kerloch P (2010). Nouvelles espèces subfossiles de rongeurs du Nord-Ouest de Madagascar. Comptes Rendus Palevol 9, 101-12.

Meiri S, Cooper N, Purvis A (2008). The island rule: made to be broken? Proceedings of the Royal Society B 275, 141-8.

Meiri S, Raia P (2010) Reptilian all the way? PNAS 107, E27.

Mittermeier R, Ganzhorn J, Konstant W et al. (2008). Lemur diversity in Madagascar. International Journal of Primatology 29, 1607-56.

Morwood MJ, Jungers WL (2009). Conclusions: implications of the Liang Bua excavations for hominin evolution and biogeography. Journal of Human Evolution 57, 640-8.

Morwood MJ, Brown P, Jatmiko et al. (2005). Further evidence for small-bodied hominins from the Late Pleistocene of Flores, Indonesia. Nature 437, 1012-7. 
Moyà-Solà S (1979). Morfología functional del tarso en el género Myotragus Bate, 1909 (Artiodactyla, Rupicaprini). Acta Geologica Hispanica 3, 87-91.

Moyà-Solà S, Köhler M, Alba D, Pons-Moyà J (2007). El significado de Myotragus batei y M. binigausensis en la evolución del género Myotragus (Bovidae, Mammalia) en las Islas Baleares. Monografies de la Societat d'Història Natural de les Balears 14, 15580.

Orr CM, Tocheri MW, Burnett SE et al. (2013). New wrist bones of Homo floresiensis from Liang Bua (Flores, Indonesia). Journal of Human Evolution 64, 109-29.

Palombo MR (2001). Paedomorphic features and allometric growth in the skull of Elephas falconeri from Spinagallo (Middle Pleistocene, Sicily). In: Cavaretta G, Gioia P, Mussi M, Palombo MR, eds. The World of Elephants. Proceedings of the 1st International Congress; 16-20 Oct 2001, Rome. CNR, Rome, pp. 492-6.

Palombo MR (2007). How can endemic proboscideans help us understand the 'island rule'? A case study of Mediterranean islands. Quaternary International 169-70, 105-24.

Palombo MR, Giovinazzo C (2005). Elephas falconeri from Spinagallo Cave (South-Eastern Sicily, Hyblean Plateau, Siracusa): brain to body weight comparison. Monografies de la Societat d'Historia Natural de les Balears 12, 255-64.

Palombo MR, Melis R (2005). Su Fossu de Cannas Cave (Sadali, central-eastern Sardinia, Italy): the oldest deposit holding megalocerine remains in the Pleistocene of Sardinia. Monografies de la Societat d'Història Natural de les Balears 12, 265-76.

Palombo MR, Bover P, Valli AMF, Alcover JA (2006). The Plio-Pleistocene endemic bovids from the Western Mediterranean islands: knowledge, problems and perspectives. Hellenic Journal of Geosciences 41, 153-62.

Palombo MR, Kohler M, Moya Sola S, Giovinazzo C (2008). Brain versus body mass in endemic ruminant artiodactyls: a case studied of Myotragus balearicus and smallest Candiacervus species from Mediterranean Islands. Quaternary International 182, 160-83.

Palombo MR, Rozzi R, Bover P (2013). The endemic bovids from Sardinia and the Balearic Islands: state of art. Geobios 46, 127-42.

Polk JD (2004). Influences of limb proportions and body size on locomotor kinematics in terrestrial primates and fossil hominins. Journal of Human Evolution 47, 237-52.

Quintana J, Agustí J (2007). Los mamíferos del Mioceno medio y superior de Menorca (Islas Baleares, Mediterráneo occiental). Geobios 40, 677-87.

Quintana J, Köhler M, Moyà-Solà S (2011). Nuralagus rex, gen. et sp. nov., an endemic insular giant rabbit from the Neogene of Minorca (Balearic Islands, Spain). Journal of Vertebrate Paleontology 31, 23140.

Raia P, Barbera C, Conte M (2003). The fast life of a dwarfed giant. Evolutionary Ecology 15, 293-312.

Reilly SM, McBrayer LD, White TD (2001). Prey processing in amniotes: biomechanical and behavioural patterns of food reduction. Comparative Biochemistry and Physiology Part A 128, 397-415.

Reumer JWF (1981). The Pleistocene small mammals from Sa Pedrera de S'Onix, Majorca (Gliridae, Soricidae). Proceedings of the Koninklijke Akademie van Wetenschappen (Series B) 84, 3-11.

Rinaldi PM, Masini F (2009). New data on the taxonomy of the endemic Myomiminae (Gliridae, Rodentia) from the Late Miocene-Early Pliocene of Gargano (southern Italy) with the description of the new species Stertomys degiulii. Bolletino della Società Paleontologica Italiana 48, 189-233.

Rofes J, Bover P, Cuenca-Bescós G, Alcover JA (2012). Nesiotites rafelinensis sp. nov., the earliest shrew (Mammalia, Soricidae) from the Balearic Islands, Spain. Palaeontologica Electronica 15.1.8A, 1-12.

Roth VL (1992). Inferences from allometry and fossils: dwarfing of elephants on islands. Oxford Surveys in Evolutionary Biology 8, 259-88.

Roth VL (1993). Dwarfism and variability in the Santa Rosa island mammoth: an interspecific comparison of limb-bone sizes and shapes in elephants. In: Hochberg FG, ed. Third California Islands Symposium: Recent Advances in Research on the California Islands. Santa Barbara Museum of Natural History, Santa Barbara, pp. 433-42.

Rozzi R, Palombo MR (2013). Do methods for predicting paleohabitats apply for mountain and insular fossil bovids? Integrative Zoology 8, 244-59.

Rozzi R, Palombo MR (2014). Lights and shadows in the evolutionary patterns of insular bovids. Integrative Zoology, doi: 10.1111/1749-4877.12055.

Rozzi R, Winkler DE, de Vos J, Schulz E, Palombo MR (2013). The enigmatic bovid Duboisia santeng (Du- 
bois, 1891) from the Early-Middle Pleistocene of Java: a multiproxy approach to its palaeoecology. $P a$ laeogeography, Palaeoclimatology, Palaeoecology 377, 73-85.

Schüle W (1993). Mammals, vegetation and the initial human settlement of the Mediterranean islands: a palaeoecological approach. Journal of Biogeography 20, 399-411.

Sondaar PY (1977). Insularity and its effect on mammal evolution. In: Hecht MN, Goody PL Hecht BM, eds. Major Patterns in Vertebrate Evolution. Plenum, New York, pp. 671-707.

Spaan A, Sondaar PY, Hartman W (1994). The structure of the evolutionary process. Geobios 27, 385-90.

Taruno H, Kawamura Y (2007). Mammoths of East Asia: a revision of their taxonomy, chromospatial distributions, evolution and immigration into Japan. $J u$ bilee Publication in Commemoration of Prof. T. Kamei's 80th Birthday, pp. 59-78.

Tocheri MW, Orr CM, Larson SG et al. (2007). The primitive wrist of Homo floresiensis and its implications for hominin evolution. Science 317, 1743-5.

van den Bergh GD (1999). The late Neogene elephantoidbearing faunas of Indonesia and their palaeozoogeographic implications. Scripta Geologica 117, $1-419$.

van den Bergh GD, Rokus Awe Due, Morwood MJ et al. (2008). The youngest Stegodon remains in southeast Asia from the Late Pleistocene archaeological site Liang Bua, Flores, Indonesia. Quaternary International 181, 16-48.

van der Geer AAE (2005). The postcranial of the deer Hoplitomeryx (Pliocene; Italy): another example of adaptive radiation on Eastern Mediterranean islands. Monografies de la Societat d'Història Natural de les Balears 12, 325-36.

van der Geer AAE (2008). The effect of insularity on the Eastern Mediterranean early cervoid Hoplitomeryx: the study of the forelimb. Quaternary International 182, 145-59. van der Geer AAE, de Vos J, Lyras G, Dermitzakis M (2006). New data on the Pleistocene Cretan deer Candiacervus sp. II (Mammalia, Cervinae). Courier Forschungsinstitut Senckenberg 256, 131-7.

van der Geer A, Lyras G, de Vos J, Dermitzakis M (2010). Evolution of Island Mammals: Adaptation and Extinction of Placetal Mammals on Islands. Wiley-Blackwell, Oxford.

van der Geer AA, Lyras GA, Lomolino MV, Palombo MR, Sax DF (2013). Body size evolution of palaeoinsular mammals: temporal variations and interspecific interactions. Journal of Biogeography 40, 144050.

van der Made J (1999). Biogeography and stratigraphy of the Mio-Pleistocene mammals of Sardinia and the description of some fossils. Deinsea 7, 337-60.

van der Made J, Palombo MR (2006). Megaloceros sar$d u s$ n. sp., a large deer from the Pleistocene of Sardinia. Hellenic Journal of Geosciences 41, 163-76.

van Heteren A, de Vos J (2008). Heterochrony as a typical island adaptation in Homo floresiensis. In: Indriati E, ed. Recent Advances on Southeast Asian Paleoanthropology and Archaeology. Proceedings International seminar on Southeast Asian Paleoanthropology; 23-29 Jul 2007, Yogyakarta, Java. Laboratory of Bioanthropology and Paleoanthropology, Faculty of Medicine, Gadjah Mada University, Yogyakarta, Indonesia, pp. 95-106.

van Valen L (1973). Pattern and the balance of nature. Evolutionary Theory 1, 31-49.

Weston EM, Lister AM (2009). Insular dwarfism in hippos and a model for brain size reduction in Homo floresiensis. Nature 459, 85-8.

Winkler DE (2010). Dentition and diet: new 3D methods help to discover dental adaptations in the extinct bovid Myotragus (MA thesis). University of Hamburg, Hamburg, Germany.

Woods CA, Sergile FC, eds (2001). Biogeography of the West Indies: Past, Present and Future, 2nd edn. CRC Press, Boca Raton, Florida. 